\title{
PENGARUH MODUL BESARAN RUANG TERHADAP TATA RUANG RUMAH SANGAT SEDERHANA
}

\author{
Lily Mauliani ${ }^{1}$, Wiwik Sudarwati ${ }^{2}$ \\ ${ }^{1}$ Prodi Arsitektur Fakultas Teknik Universitas Muhammadiyah Jakarta \\ ${ }^{2}$ Prodi Teknik Industri Fakultas Teknik Universitas Muhammadiyah Jakarta \\ lilysidi@ymail.com
}

\begin{abstract}
ABSTRAK. Bangunan rumah sangat sederhana pada permukiman padat penduduk pada umumnya merupakan bangunan yang tidak memenuhi syarat kelayakan sebuah hunian, Ketidaklayakan bangunan rumah tidak saja dari segi luasan masing-masing ruang di dalamnya tetapi juga dari segi kenyamanan ruang yang mencakup pencahayaan, penghawaan serta penataan perabot di dalam ruang. Metode penelitian yang digunakan untuk mengetahui korelasi antara besaran ruang dan tata ruang rumah sangat sederhana ini adalah metode deskriptif, berdasarkan fenomena yang terjadi di lapangan. Modul besaran ruang rumah sangat sederhana yang relatif sangat kecil menuntut adanya penyelesaian pada disain tata ruangnya. Dengan modul besaran ruang rumah sangat sederhana sebesar $3 \times 3 \mathrm{~m}^{2}$ pemecahan masalah yang dapat dilakukan adalah dengan menata ruang dengan sistem split level. Dengan sistem tersebut memungkinkan terjadinya pemisahan ruang privat berdasarkan jenis kelamin serta pengoptimalan pencahayaan dan penghawaan alami.
\end{abstract}

Kata Kunci: modul, besaran ruang, tata ruang

ABSTRACT. A simple residential building in densely populated settlements, generally, is a building that does not meet the requirement of a dwelling, not laying the house not only in terms of the area of each space in it but also in terms of comfort space that includes lighting, air conditioning and the arrangement of furniture within a room. The research method that has been used to find out the correlation between space and spatial layout of this simple house is a descriptive method, based on phenomena that occurred in the field. Module size of the house space is very simple which is relatively minimal demands the completion of its spatial design. With the module size of a very simple home space $3 \times 3 \mathrm{~m} 2$ problem solving can be done to arrange space with a split-level system. With such an arrangement allows the separation of private areas by sex and optimization of natural lighting and air conditioning.

Keywords: module, dimension of space, layout

\section{PENDAHULUAN}

Ruang-ruang pada rumah sangat sederhana pada umumnya memiliki ukuran yang sangat kecil yang diakibatkan sempitnya lahan yang menjadi tempat berdirinya bangunan rumahrumah tersebut.

Dengan kondisi ukuran ruang yang kecil dan terbatasnya jumlah ruang pada rumah-rumah sangat sederhana mengakibatkan tidak optimalnya kegiatan-kegiatan yang dapat dilakukan di setiap ruang dan terjadinya pemakaian ruang secara tumpang tindih. Sebagai contoh ruang tamu yang seharusnya digunakan untuk ruang menerima tamu harus digunakan juga untuk kegiatan menonton tv, menyetrika pakaian bahkan juga sebagai ruang tidur di malam hari. Demikian juga dengan ruang-ruang lainnya yang harus berfungsi ganda. Selain itu kondisi ruangruang di dalam rumah sangat sederhana ini sangat jauh dari standar kenyamanan ruang, terutama dari segi besaran ruang, pencahayaan dan penghawaan ruang. Hal tersebut disebabkan oleh terbatasnya luas lahan dan rapatnya jarak antar bangunan yang berdampak pada terbatasnya bidang untuk menempatkan bukaan.

Berdasarkan pengamatan tersebut di atas, dicoba untuk membuat modul besaran ruang yang sesuai dengan kebutuhan masyarakat yang tinggal di rumah-rumah sangat sederhana di perumahan padat penduduk. Modul besaran ruang tersebut dibuat dengan mengacu pada standar besaran ruang yang telah ditetapkan oleh pemerintah untuk rumah sederhana sehat, yang dikembangkan dari standar Rumah Inti Tumbuh (RIT).

\section{Luasan dan Tata Ruang Eksisting Rumah Sangat Sederhana di Pademangan}

Salah satu permasalahan yang cukup penting dari berbagai masalah yang ada pada permukiman padat penduduk adalah luas lahan yang sangat kecil dan secara berurutan 
akan berdampak pada luasan bangunan, luasan masing-masing ruang di dalamnya dan penggunaan ruang-ruang yang saling tumpang tindih.

Pada studi kasus permukiman padat penduduk di Pademangan ini, luasan lahan yang dimiliki oleh setiap kepala keuarga (KK) pada umumnya jauh dibawah luasan lahan standar yang ditetapkan pemerintah. Luas lahan standar untuk rumah sederhana adalah $60 \mathrm{~m}^{2}$ sementara luasan lahan di permukiman padat ini berkisar antara $15 \mathrm{~m}^{2}$ sampai dengan 50 $\mathrm{m}^{2}$. Dengan luas lahan yang sedemikian kecilnya maka tidak memungkinkan bagi warga untuk memperluas bangunannya ke arah horisontal, sehingga hampir semua bangunan rumah di wilayah ini berkembang ke arah vertikal.

Pembangunan ke arah vertikal menuntut adanya persyaratan-persyaratan tertentu berkaitan dengan kenyamanan dan keamanan hunian baik secara individual maupun secara komunal, seperti jarak antar bangunan, GSB, KLB, dan sebagainya. Namun persyaratanpersyaratan tersebut terpaksa diabaikan demi terpenuhinya kebutuhan akan tempat tinggal yang dapat mengakomodasi semua kegiatan penghuninya. Jumlah lantai pada bangunanbangunan rumah tinggal tersebut berkisar antara 2 sampai 3,5 lantai, sesuai kemampuan ekonomi penghuni . Semakin 'mampu' secara ekonomi maka jumlah lantai bangunan akan semakin bertambah.

Fenomena bertambahnya jumlah lantai yang sejalan dengan naiknya kemampuan ekonomi, tetap berada di dalam batasan bangunan sangat sederhana. Hal tersebut dapat dilihat dari material bangunan yang digunakan seperti material lantai atas yang terbuat dari papan, dinding-dinding partisi dari kayu tripleks dan furnitur yang digunakan merupakan furnitur yang sederhana bahkan tanpa furnitur.

Bangunan-bangunan rumah yang ada di wilayah Pademangan bersifat permanen dalam arti struktur dan selubung bangunan menggunakan struktur beton dan dinding bata yang diplester, hanya ruang-ruang bagian dalam yang menggunakan partisi-partisi kayu tripleks. Untuk area-area basah seperti kamar mandi/wc dan dapur dibuat dengan material permanen. Pada umumnya lantai satu di rumah-rumah ini menggunakan finishing lantai keramik dan dibuat dengan peninggian lantai hingga mencapai $50 \mathrm{~cm}$. Hal tersebut dimaksudkan untuk mengantisipasi air masuk ke dalam rumah pada saat terjadi banjir.
Ruang-ruang pada bangunan rumah sangat sederhana di wilayah Pademangan ini ratarata berjumlah 3 sampai 5 ruang, yang terdiri dari ruang tamu, ruang tidur, kamar mandi/wc, dapur dan balkon. Masing-masing ruang tersebut memiliki fungsi ganda, terutama ruang tamu yang tidak saja digunakan untuk menerima tamu tetapi juga untuk berkumpul keluarga, ruang setrika dan pada malam hari juga digunakan sebagai ruang tidur. Jumlah anggota keluarga yang menempati rumah sangat sedehana ini berkisar antara 3-7 orang dan bisa terdiri dari $1 \mathrm{KK}-2 \mathrm{KK}$.

Penggunaan ruang-ruang secara tumpang tindih tersebut di atas disebabkan oleh faktor keterbatasan jumlah ruang yang tidak sebanding dengan jumlah penghuni. Ruang tamu yang menempati posisi utama di lantai satu dan berukuran relatif lebih luas dibandingkan dengan ruang-ruang lainnya, menjadi ruang pusat kegiatan di dalam rumah. Sedangkan ruang tidur merupakan ruang yang paling jarang digunakan secara bersamaan dengan fungsi lainnya. Faktor-faktor yang menyebabkan hal tersebut terjadi adalah karena posisi ruang tidur pada umumya berada di lantai atas, luasan ruang yang sempit dan kenyamanan ruang yang minim (gelap dan panas).

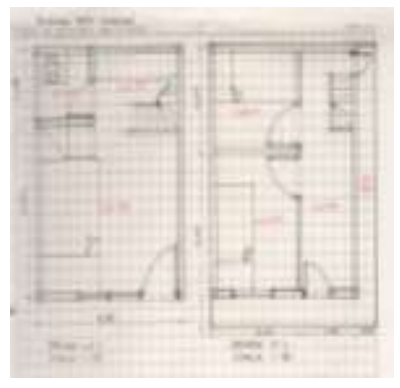

Gambar 1. Rumah Tinggal dengan Luas Bangunan $15 \mathrm{~m}^{2}$

Sumber : Dokumentasi Pribadi

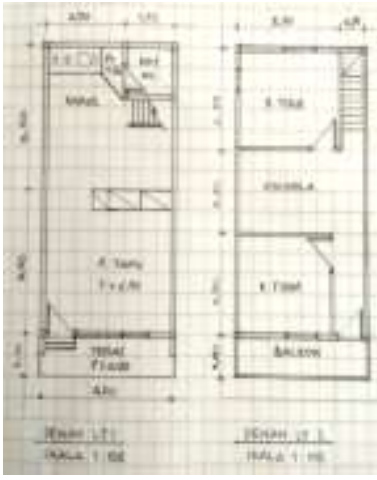

Gambar 2. Rumah Tinggal dengan Luas Bangunan $32 \mathrm{~m}^{2}$

Sumber : dokumentasi pribadi 


\section{METODE PENELITIAN}

Metode penelitian yang digunakan untuk mengetahui korelasi antara besaran ruang dan tata ruang rumah sangat sederhana ini adalah metode deskriptif, berdasarkan fenomena yang terjadi di lapangan.

\section{ANALISIS KONDISI RUMAH SANGAT SEDERHANA}

Pembahasan tentang rumah tinggal tidak terbatas pada pembahasan tentang bentuk fisik semata tetapi lebih jauh dari itu adalah pembahasan terpadu antara fisik bangunan dan manusia penghuninya. Jika menyangkut pembahasan tentang penghuni rumah tinggal maka pembahasan akan menjadi sangat kompleks karena banyaknya faktor yang terkait dengan penghuni tersebut. Faktor-faktor tersebut dapat kita golongkan dalam 2 kelompok bahasan yaitu yang menyangkut fisik dan psikologis penghuni. Pembahasan penelitian ini akan difokuskan pada faktor fisik dari bangunan rumah tinggal sangat sederhana yang terkait dengan ukuran ruang, tata ruang dalam dan kenyamanan ruang dari segi pencahayaan dan penghawaan alami ruang.

\section{Ukuran Ruang}

Luasan lahan dan luasan bangunan yang dapat dimiliki oleh setiap kepala keluarga tergantung pada penghasilan yang dapat diperoleh kepala keluarga yang bersangkutan. Berdasarkan Pedoman Umum Rumah Sederhana Sehat [1] penghasilan masyarakat dapat dibagi dalam 3 kategori yaitu :

- Masyarakat berpenghasilan rendah

- Masyarakat berpenghasilan sangat rendah

- Masyarakat berpenghasilan informal

Untuk ketiga kategori tersebut pemerintah mentargetkan hunian dengan standar ukuran bangunan seluas $36 \mathrm{~m}^{2}$ yang digolongkan sebagai Rumah Sederhana Sehat. Pencapaian target Rumah Sederhana Sehat tersebut dengan mempertimbangkan pentahapan pembangunannya sesuai dengan kemampuan ekonomi masyarakat. Menurut standar tersebut harus ada Rumah Antara yaitu Rumah Inti Tumbuh ( $R$ I $T$ ) untuk menunggu masyarakat mampu memiliki Rumah Sederhana Sehat.

Adapun Rumah Antara atau RIT ini minimal harus terdiri :

- 1 ruang tertutup yang berfungsi sebagai ruang tidur
- 1 ruang terbuka beratap yang berfungsi sebagai ruang serba guna

- $1 \mathrm{MCK}$

Sedangkan standar ukuran ruang untuk Rumah Sederhana Sehat adalah $9 \mathrm{~m}^{2}$ per orang atau standar ambang $7,2 \mathrm{~m}^{2}$ per orang. Dengan standar ukuran tersebut maka didapat luasan Rumah Antara atau RIT adalah $21 \mathrm{~m}^{2}$.

Lebih lanjut dijelaskan pada Pedoman Umum Rumah Sederhana Sehat[1] tentang modul yang dapat digunakan untuk merancang Rumah Antara/RIT sebagai berikut :

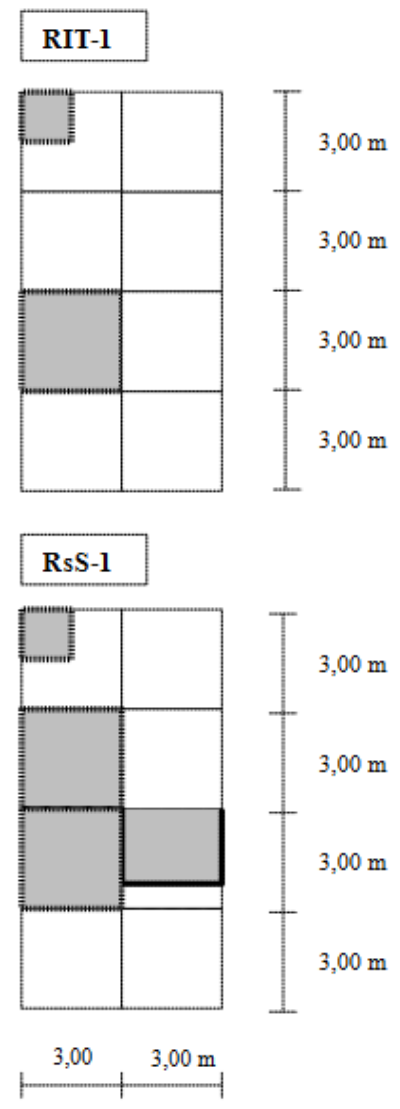

Gambar 3. Modul Ruang Rumah Antara/RIT Sumber : Pedoman Umum Rumah Sederhana Sehat [1]

Dari gambar tersebut di atas dapat dilihat bahwa modul Rumah Antara/RIT berukuran lebar tapak $6 \mathrm{~m}$ dan panjang $12 \mathrm{~m}$ dengan luas efektif lahan $72 \mathrm{~m}^{2}$, sementara rumahrumah sangat sederhana di wilayah pademangan memiliki ukuran lebar tapak berkisar antara 3-4 m dan panjang antara 4 - $12 \mathrm{~m}$. Dengan ukuran lahan yang demikian maka akan sulit dikembangkan menjadi Rumah Sederhana Sehat yang sesuai dengan standar pemerintah.

Jika menelaah ukuran-ukuran ruang yang ada pada bangunan sangat sederhana di 
permukiman padat penduduk Pademangan, maka ukuran-ukuran ruang tersebut telah memenuhi standar ukuran ruang Rumah Antara/RIT yang hanya $21 \mathrm{~m}^{2}$, namun jika dilihat dari luasan bangunan secara keseluruhan maka untuk rumah tinggal sangat sederhana di Pademangan ini harus dicarikan solusi-solusi disain yang lain agar tetap dapat memenuhi kriteria Rumah Sederhana Sehat yang disesuaikan dengan standar pemerintah.

Ukuran sebuah ruang dapat mempengaruhi penghuni sebuah bangunan baik secara ragawi/fisik maupun secara jiwani/psikologis, menurut [5] ukuran ruang terbagi dalam 2 bagian yaitu ukuran Luas ruang $(P \times L)$, dan ukuran Tinggi ruang $(T)$. Lebih lanjut dijelaskan bahwa ukuran Luas ruang berpengaruh pada nilai kecukupan ruang (muat atau tidak muat) yang ditentukan oleh kapasitas ruang yang bersangkutan. Sedangkan Tinggi ruang akan berpengaruh pada kondisi jiwani penghuni seperti rasa tertekan, merasa 'kecil' dan lain sebagainya. Pengaruh-pengaruh fisik dan psikologis dari ukuran-ukuran tersebut di atas juga berlaku pada bangunan rumah tinggal, dimana untuk rumah tinggal sangat sederhana ukuran-ukuran tersebut merupakan problema utama yang ada pada setiap rumah.

Berdasarkan pengamatan di lapangan ukuranukuran ruang yang sangat krusial untuk diperhatikan adalah ukuran Luas ruang, karena pada umumnya ukuran Luas $(P \times L)$ ruang-ruang yang ada pada rumah-rumah sangat sederhana ini tidak dapat memenuhi kebutuhan fisik penghuninya. Sedangkan ukuran Tinggi $(T)$ sudah cukup memenuhi standar kebutuhan psikologisnya yaitu antara $2,5 \mathrm{~m}-3 \mathrm{~m}$, meskipun secara kenyamanan ruang belum memenuhi persyaratan karena penghawaan dan pencahayaan yang masih minim. Penyebab tidak memadainya ukuran Luas ruang untuk memenuhi kebutuhan fisik adalah karena faktor jumlah penghuni yang melebihi kapasitas yang seharusnya dan jumlah ruang yang tidak sesuai dengan jumlah penghuni yang berdampak pada tumpang tindihnya beberapa fungsi pada satu ruang.

\section{Tata Ruang}

Tata ruang pada rumah tinggal di Pademangan ini secara umum sudah dapat dikategorikan cukup baik, dalam arti zoning publik, privat dan servis sudah terpisah secara jelas, namun pada praktek penggunaannya yang tumpang tindihlah yang meyebabkan zoning menjadi tidak sesuai lagi dengan yang seharusnya. Untuk Ruang-ruang yang bersifat publik seperti teras dan ruang tamu berada di lantai 1, ruang-ruang servis seperti dapur dan kamar mandi/wc berada di lantai 1, sedangkan ruang-ruang privat seperti ruang-ruang tidur berada di lantai 2. Ruang-ruang tidur yang masuk ke dalam zoning privat adakalanya bercampur dalam zoning publik dikarenakan keterbatasan jumlah ruang dan berlebihnya jumlah penghuni. Ruang tidur pada malam hari pada umumnya berpindah ke ruang tamu yang pada siang haripun ruang tamu ini lebih banyak berfungsi sebagai ruang serba guna.

\section{Kenyamanan Ruang}

Kenyamanan adalah segala sesuatu yang memperlihatkan dirinya sesuai dan harmonis dengan penggunaan suatu ruang, baik dengan ruang itu sendiri maupun dengan berbagai bentuk, tekstur, warna, simbol maupun tanda, suara dan bunyi kesan, intensitas dan warna cahaya maupun bau atau apapun juga.

Kenyamanan ruang biasanya dipengaruhi oleh tata pencahayaan dan penghawaan. Dua elemen ini sangat penting untuk diperhatikan agar ruang-ruang di dalam bangunan mendapat pencahayaan dan penghawaan alami cukup, sehingga dapat memberikan kenyamanan bagi pemakai dalam melakukan aktivitasnya. Ruang-ruang yang memiliki penghawaan dan pencahayaan alami baik juga akan memiliki kelembaban udara cukup, sehingga kesehatan lingkungan tetap terjaga. Selain itu, memiliki penghawaan dan pencahayaan alami yang cukup berarti menghemat energi listrik yang diperlukan, karena tidak tergantung pada pencahayaan dan penghawaan buatan.

Kenyamanan penghuni rumah tipe kecil sebenarnya dapat diciptakan dengan cara penataan ruang dan bangunan yang sesuai dengan kaidah Perancangan rumah sederhana sehat. Berdasarkan potret penduduk dan pemukinan di wilayah pademangan, maka bisa dianalisis tingkat kenyamanan penghuni berdasarkan :

1. Luas Tanah dan bangunan

Hasil survey menunjukkan bahwa di wilayah pademangan banyak rumah dengan tipe kecil dengan luas tanah < dari 60 meter persegi, diantaranya dengan luas $20 \mathrm{~m}^{2}, 30 \mathrm{~m}^{2}$, dan 40 $\mathrm{m}^{2}$. Luas bangunan rumah tersebut masih belum memenuhi standar minimal kebutuhan ruangan [1]. 


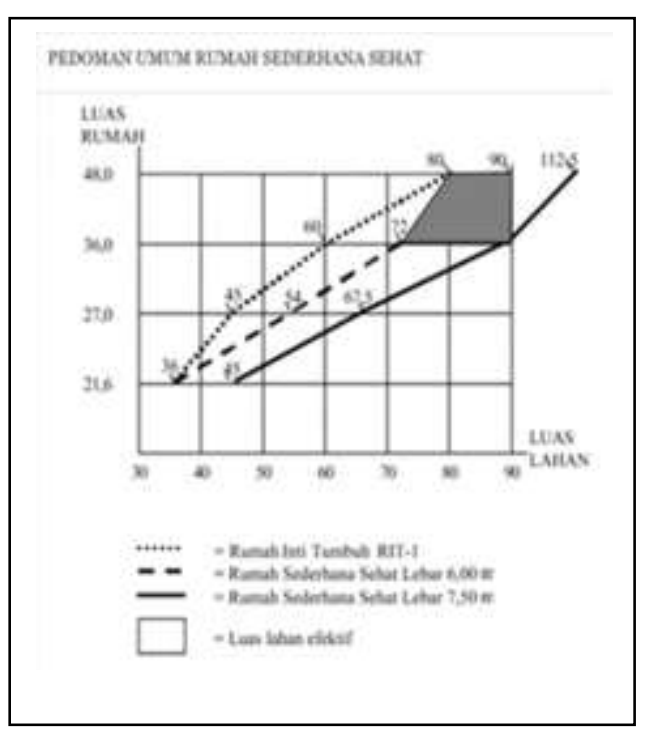

Gambar 4. luas bangunan rumah sederhana sehat dan luas lahan efektif, diperhitungkan terhadap kebutuhan ruang minimal dan koordinasi modular sehingga dicapai luas lahan efektif antara $72 \mathrm{~m}^{2}$ sampai dengan $90 \mathrm{~m}^{2}$ dengan variasi lebar muka lahan yang berbeda.[1]

Berdasarkan data hasil survey yang telah dilakukan diketahui bahwa luas rumah yang berada di wilayah pademangan sangat tidak memenuhi standar minimal rumah sederhana sehat yaitu luas lahan $72 \mathrm{~m}^{2}$ sampai dengan $90 \mathrm{~m}^{2}$.

Untuk memperoleh kenyamanan dan dapat melakukan seluruh aktivitas dalam rumah dengan luas lahan dan bangunan yang sempit ini maka warga membuat bangunan 2 lantai (rumah inti tumbuh). Tetapi karena tingkat kepadatan yang tinggi, dan hampir semua bangunan adalah rumah inti tumbuh dan disertai tingkat pengetahuan warga pademangan yang kurang terhadap perencanaan pembangunan rumah yang sesuai dengan kaidah hidup sehat maka secara rata - rata pembanganan rumah inti tunbuh tersebut masih kurang memenuhi standar minimal rumah sederhana sehat.

\section{Jumlah dan Luas ruangan}

Jumlah ruangan yang dimiliki oleh penghuni rumah dengan luas bangunan kecil tersebut rata - rata sebanyak 5 ruangan yaitu ruang tidur sebanyak 2 ruangan, ruang tamu sekaligus sebagai ruang keluarga dan ruang makan sebanyak 1 ruangan, 1 ruang dapur, dan1 kamar mandi. Ukuran ruangan tersebut sebagai berikut :
Tabel 1. Data luas ruangan dalam hunian sangat Sederhana

\begin{tabular}{|l|c|c|c|}
\hline Ruang & \multicolumn{3}{|c|}{ Luas Ruangan } \\
\hline & Rumah 1 & Rumah 2 & Rumah 3 \\
\hline Teras & $3,5 \times 0,85$ & $3,5 \times 1,2$ & $4 \times 0,85$ \\
\hline Ruang Tamu & $3,5 \times 3$ & $3,5 \times 3$ & $4 \times 3,5$ \\
\hline Ruang Makan & & $3,5 \times 2$ & \\
\hline Kamar Tidur 1 & $2,5 \times 2,1$ & $3,5 \times 3,5$ & $3,30 \times 2,5$ \\
\hline Kamar Tidur 2 & $2,0 \times 2,1$ & $3,5 \times 4$ & $3,30 \times 2,5$ \\
\hline Kamar Mandi & $1,25 \times 1,25$ & $3,5 \times 1,5$ & $1,25 \times 1,5$ \\
\hline Dapur & $2 \times 2,25$ & $3,5 \times 1,2$ & $2 \times 2,25$ \\
\hline $\begin{array}{l}\text { Jumlah } \\
\text { penghuni }\end{array}$ & 9 orang & 5 orang & 4 orang \\
\hline
\end{tabular}

Sumber : hasil pengumpulan data, 2017

Berdasarkan tabel diatas terlihat bahwa ukuran ruangan yang digunakan termasuk kecil dan belum memenuhi standar minimal ruangan. Menurut [2] Kebutuhan ruang minimal menurut perhitungan dengan ukuran Standar Minimal adalah $9 \mathrm{~m}^{2}$, atau standar ambang dengan angka $7,2 \mathrm{~m}^{2}$ per orang. Sehingga secara rata - rata rumah warga pademangan bisa dikatakan belum memenuhi standar minimal karena luas yang harus dimiliki seharusnya adalah menyesuaikan berapa jumlah penghuni dalam rumah tersebut. Misalkan rumah 1 luas tanah $20 \mathrm{~m}^{2}$. Dengan jumlah penghuni sebanyak 9 orang seharusnya memiliki luas tanah minimal $65 \mathrm{~m}^{2}$. Walaupun ada juga warga yang luas rumahnya telah memenuhi standar minimal rumah sederhana sehat.

Tabel 2. Data standar Luas ruangan [2]

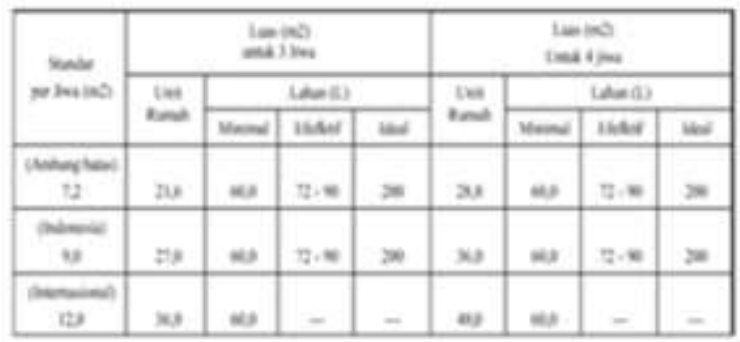

Sedangkan untuk jumlah ruangan yang dimiliki secara standar ruang-ruang yang perlu disediakan sekurang-kurangnya terdiri dari:

- 1 ruang tidur yang memenuhi persyaratan keamanan dengan bagian- bagiannya tertutup oleh dinding dan atap serta memiliki pencahayaan yang cukup.

- 1 ruang serbaguna merupakan ruang kelengkapan rumah dimana di dalamnya dilakukan interaksi antara keluarga dan dapat melakukan aktivitas-aktivitas lainnya.

- 1 kamar mandi/kakus/cuci marupakan bagian dari ruang servis yang sangat menentukan apakah rumah tersebut dapat 
berfungsi atau tidak, khususnya untuk kegiatan mandi cuci dan kakus

Ukuran pembagian ruang dalam rumah tersebut berdasarkan pada satuan ukuran modular dan standar internasional untuk ruang gerak/kegiatan manusia. Sehingga diperoleh ukuran ruang-ruang dalam RIT-1 adalah sebagai berikut:

- Ruang Tidur : 3,00 m x 3,00 m

- Serbaguna : 3,00 m x 3,00 m

- Kamar mandi/kakus/cuci : 1,20 m x 1,50 m Luas ruangan rumah warga pademangan masih banyak yang belum memenuhi standar minimal rumah sederhana sehat walaupun dari segi jumlah ruang tidur sebanyak 2 ruang, sudah memenuhi standar namun dengan ukuran yang lebih kecil yaitu $2 \times 2 \mathrm{~m}^{2}$.

\section{Pencahayaan}

Matahari sebagai potensi terbesar yang dapat digunakan sebagai pencahayaan alami pada siang hari. Pencahayaan yang dimaksud adalah penggunaan terang langit, dengan ketentuan sebagai berikut:

- cuaca dalam keadaan cerah dan tidak berawan,

- ruangan kegiatan mendapatkan cukup banyak cahaya,

- ruang kegiatan mendapatkan distribusi cahaya secara merata

Letak rumah yang saling berdempetan antara satu rumah dengan rumah lain membuat rumah tersebut tidak memiliki bukaan yang cukup untuk masuknya udara dan cahaya. Selain luas bangunan yang sempit dan tidak cukup bukaan, arah posisi hadap rumah juga menentukan baik dan buruknya pencahayaan dalam rumah tersebut.

Tidak cukupnya bukaan tersebut diakibatkan karena menempelnya sisi dinding rumah yang satu dengan rumah yang lain. Hal ini membuat pencahayaan di rumah tersebut menjadi kurang dan tidak sesuai dengan standar pencahanyaan.

\section{Sirkulasi Udara}

Udara merupakan kebutuhan pokok manusia untuk bernafas sepanjang hidupnya [3]. Udara akan sangat berpengaruh dalam menentukan kenyamanan pada bangunan rumah. Kondisi Rumah warga saat ini dirasakan masih belum memenuhi kaidah perencanaan rumah sederhana sehat. Masalah pertukaran udara alami yang tidak terjadi secara optimal menjadi salah satu penyebab rumah-rumah sangat sederhana ini tidak nyaman.

\section{MODUL BESARAN RUANG}

Untuk mendapatkan pola tata ruang yang lebih teratur dan memenuhi syarat ruang yang memadai, ruang-ruang pada bangunan sangat sederhana harus memiliki besaran yang dapat distandarkan. Standar tersebut bisa didapatkan jika besaran ruang-ruang di dalamnya dirancang dengan sistem modul.

Modul besaran ruang pada bangunan rumah sangat sederhana di Pademangan dapat ditetapkan berdasarkan modul besaran ruang Rumah Sederhana Sehat yang ditetapkan pemerintah. Modul besaran ruang Rumah Sederhana Sehat yang dikembangkan dari modul besaran ruang Rumah Inti Tumbuh memiliki ukuran $3 \times 3 \mathrm{~m}^{2}$.

Modul ruang standar untuk Rumah Inti Tumbuh tersebut di atas dapat dikembangkan secara horisontal baik ke arah lebar maupun ke arah panjangnya. Pengembangan modul tersebut diterapkan terlebih dahulu pada penentuan luas lahan, sebagai tempat dibangunnya Rumah Sederhana Sehat, sehingga modul besaran ruang-ruang pada bangunan Rumah Sederhana Sehat akan sesuai dengan modul luasan lahannya.

Dari hasil pengamatan di lapangan terhadap rumah-rumah sangat sederhana di wilayah Pademangan didapatkan ukuran luas lahan berkisar antara adalah $15 \mathrm{~m}^{2}-50 \mathrm{~m}^{2}$ dengan ukuran lebar lahan antara 3 - 3,5 m dan ukuran panjang 4,5 - $13 \mathrm{~m}$. Dengan ukuran luas lahan yang demikian sempit dan posisi yang berderet hampir tanpa jarak, menyebabkan pengembangan rumah dilakukan ke arah vertikal.

Berdasarkan pengamatan tentang ukuran luas lahan dan ukuran ruang pada bangunan rumah-rumah sangat sederhana di Pademangan Barat tersebut dapat dirumuskan konsep modul besaran ruang yang mengacu pada ukuran standar pemerintah untuk Rumah Sederhana Sehat, yaitu $3 \times 3 \mathrm{~m}^{2}$. Hal terpenting yang dapat dilihat dari penerapan modul besaran ruang pada rumah sangat sederhana tersebut adalah kemungkinan pengembangan yang terutama hanya dapat dilakukan ke arah vertikal, dan sedikit ke arah horisontal dengan modul lebar bangunan $3 \mathrm{~m}$. Modul terkecil dari modul $3 \times 3 \mathrm{~m}^{2}$ adalah $1 \times 1$ $\mathrm{m}^{2}$ dengan kemungkinan pengembangan ukuran $1 / 2$ - 1 modul dari modul terkecil ke arah horisontal dan $1 / 2 ; 1 ; 2$ dan 3 modul dari modul terkecil $1 \times 1 \mathrm{~m}^{2}$ ke arah vertikal. 


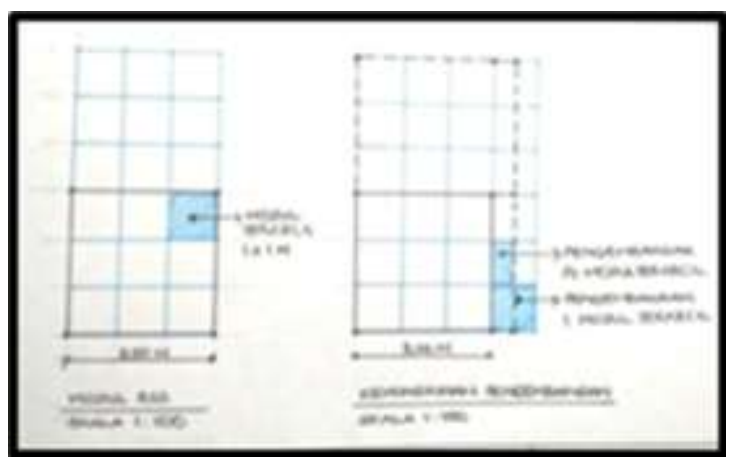

Gambar 5. Kemungkinan Pengembangan Modul Ruang Pada Rumah Sangat Sederhana (Sumber: Analisis, 2017)

\section{TATA RUANG BERDASARKAN MODUL BESARAN RUANG}

\section{Tata Ruang Rumah Sangat Sederhana}

Telah dijelaskan sebelumnya bahwa ruangruang pada rumah sangat sedehana di permukiman padat penduduk tersebut digunakan secara tumpang tindih dalam arti satu ruang digunakan untuk beberapa kegiatan yang berbeda. Hal tersebut terutama terjadi pada ruang tamu, yang digunakan tidak saja sebagai ruang menerima tamu tetapi juga digunakan untuk ruang berkumpul keluarga, ruang setrika dan ruang tidur pada malam hari. Untuk rumah-rumah sangat sederhana di permukiman padat yang luas lahan dan luas ruang-ruangnya sangat sempit, ruang tamu menjadi ruang pusat kegiatan. Sebagai ruang pusat kegiatan ruang tamu ini pada umumnya memiliki ukuran luas yang paling besar, ratarata berkisar antara $9-12 \mathrm{~m}^{2}$. Sedangkan ruang-ruang lainnya seperti ruang-ruang servis dan ruang-ruang tidur memiliki luas rata-rata 3 $-5 \mathrm{~m}^{2}$.

Penggunaan ruang tamu yang multi fungsi menyebabkan bercampurnya zoning publik, servis dan privat. Tercampurnya zoning publik dengan servis untuk masyarakat di permukiman padat masih dapat ditolerir jika kita melihatnya dari beberapa sisi. Pertama adalah dari sisi sempitnya lahan dan berhimpitannya antara satu rumah dengan rumah lainnya. Hal ini mendorong masyarakat penghuni rumah-rumah sangat sederhana ini untuk bersikap terbuka dalam arti harus dapat menerima rumahnya dijadikan sebagai tempat berkumpulnya tetangga di ruang tamu yang hampir tak berjarak dengan akses jalan di depan rumah. Akses jalan di depan rumah tersebut juga menjadi tempat berkumpul di pagi dan siang hari, terutama bagi para ibu dan anak-anak balita.
Sisi lain dari penyebab tercampurnya zoning publik dengan servis adalah terbatasnya jumlah ruang yang ada pada bangunan rumah sangat sederhana ini.

Permasalahan terbesar yang harus dipikirkan oleh perancang bangunan dalam membuat rancangan rumah sangat sedehana adalah masalah bercampurnya zoning publik dengan privat. Seperti telah dijelaskan sebelumnya bahwa ruang tamu di rumah sangat sederhana ini pada malam hari akan berubah fungsi menjadi ruang tidur, yang digunakan secara bersamaan baik oleh orang tua maupun anak-anak. Pencampuran penggunaan ruang tamu sebagai ruang tidur tidak saja mencampur adukkan usia pengguna tetapi juga jenis kelamin.

Dalam penzoningan ruang pada rumah tinggal, ruang tidur berada pada zoning privat, yang merupakan zona sangat pribadi dimana penghuni ruang tidur tersebut dapat melakukan kegiatan apapun secara bebas tanpa diganggu oleh orang lain. Dari pengertian tersebut dapat difahami bahwa sebuah ruang tidur hanya dapat digunakan secara pribadi baik oleh sepasang suami istri maupun secara individu oleh anak-anak. Pemisahan penggunaan ruang tidur baik secara agama maupun secara adat budaya timur akan didasarkan pada jenjang usia dan jenis kelamin. Anak-anak dengan usia dibawah lima tahun harus sudah dipisahkan ruang tidurnya dari ruang tidur orang tua, demikian pula anak-anak dengan jenis kelamin berbeda harus tidur secara terpisah.

Aturan-aturan pemisahan ruang tidur tersebut di atas sangat sulit untuk diterapkan pada rumah sangat sederhana, karena terbentur oleh keterbatasan jumlah dan sempitnya ukuran ruang. Berdasarkan pengamatan di lapangan didapatkan fakta bahwa para orang tua yang masih memiliki anak-anak usia balita (di bawah lima tahun) dan bahkan usia pra remaja (usia Sekolah Dasar) harus berbagi ruang untuk tidur. Hal tersebut menyebabkan para orang tua harus dapat mensiasati waktuwaktu untuk kegiatan yang harus dilakukan secara pribadi oleh pasangan suami istri. Salah satu dampak buruk yang dikhawatirkan akan timbul dari tidak berfungsinya ruang tidur sebagai ruang privat seperti yang telah dijelaskan tersebut di atas adalah perilaku seksual generasi muda di masa depan yang tidak berjalan sesuai dengan norma-norma agama. Meskipun penyebab penyimpangan perilaku dapat disebabkan oleh berbagai 
macam faktor namun faktor besaran dan tata ruang pada sebuah rumah memiliki andil yang cukup besar dalam pembentukan perilaku setiap individu penghuninya.

Pada pembahasan tata ruang sebelumnya, telah dijelaskan bahwa tata ruang pada rumahrumah sangat sederhana di wilayah Pademangan ini sudah cukup baik dalam arti sudah ada pemisahan antara zoning publik dan servis dengan zoning privat, dimana zoning publik dan servis berada di lantai bawah dan zoning privat berada di lantai atas. Penataan berdasarkan zoning tersebut akan tetap dipertahankan namun akan lebih diperjelas dalam hal penggunaan ruangnya.

Jumlah ruang yang sangat terbatas yaitu antara $3-5$, dimana jumlah tersebut sudah termasuk ruang-ruang servis (kamar mandi/wc dan dapur), akan dioptimalkan fungsi dan penggunaannya. Pengoptimalan penggunaan ruang yang dimaksud terutama untuk ruangruang tidur baik ruang tidur untuk orang tua maupun untuk anak-anak. Pemisahan ruang tidur untuk anak-anak dapat diperjelas berdasarkan jenis kelamin sedangkan pemisahan ruang tidur berdasarkan usia tidak menjadi prioritas, walaupun hal tersebut masih memungkinkan untuk dilakukan jika kemampuan penghuni secara ekonomi meningkat.Pemisahan ruang-ruang tidur anak dilakukan dengan mengelompokkan anak lakilaki pada satu ruang tidur dan kelompok anak perempuan pada ruang tidur lainnya.

Jumlah ruang tidur yang hanya 2 ruang (1 ruang tamu yang merangkap ruang tidur dan 2 ruang tidur yang sesungguhnya) harus ditambah minimal dengan 1 ruang tidur baru atau jika tidak memungkinkan maka penataan dan penggunaan ruang tamu sebagai ruang tidur harus disesuaikan dengan tataan interior ruang yang fleksibel. Berdasarkan kemungkinan pengembangan modul besaran ruang ke arah vertikal maka penambahan ruang pada rumah sangat sederhana ini juga harus dilakukan ke arah vertikal. Menurut [4] sebuah bentuk dapat diubah dengan cara penambahan, pengurangan atau perubahan dimensi. Untuk disain rumah-rumah sangat sederhana metode penambahan dan pengurangan pada sebuah bentuk (bentuk aditif dan substraktif) dapat diterapkan baik untuk tujuan pengembangan bangunan ke arah vertikal maupun untuk memasukkan pencahayaan dan penghawaan alami ke dalam rumah.

Pada saat pengembangan ke arah vertikal, tata ruang pada disain rumah sangat sederhana dapat disusun dengan sistem split level, suatu penyusunan dengan tidak menaikkan ruang secara penuh setinggi satu lantai. Sistem split level ini adalah menaikkan ruang dengan ketinggian $1 / 2$ dari tinggi ruang yang utuh, dengan posisi $1 / 2$ tinggi ruang atas bagian bawah berada pada $1 / 2$ ketinggian ruang bawah bagian atas dan $1 / 2$ bagian atas ruang atas berada di posisi $1 / 2$ bagian atas ruang bawah. Ada beberapa keuntungan dari penambahan ruang dengan sistem split level, antara lain terdapatnya ruang terbuka yang dapat difungsikan sebagai ruang terbuka, pemisahan fungsi yang jelas dan optimalisasi pencahayaan dan penghawaan di dalam ruang

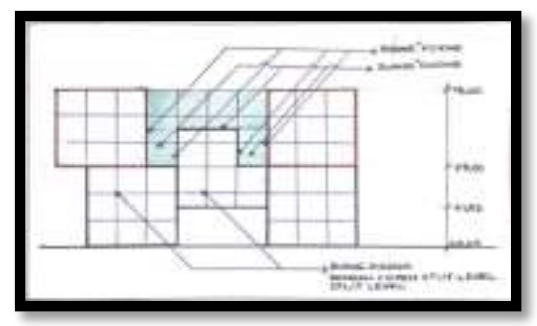

Gambar 6. Penyusunan Ruang dengan sistem split level

(Sumber: Analisis, 2017)

Pengurangan bentuk [4] dapat diterapkan pada disain tata ruang rumah-rumah sangat sederhana terutama untuk tujuan memasukkan pencahayaan dan penghawaan alami ke dalam rumah. Metode pengurangan bentuk pada bangunan rumah-rumah sangat sederhana merupakan metode yang paling tepat dengan mempertimbangkan letak antar rumah yang saling berhimpitan satu dengan lainnya. Sama halnya dengan sistem split level, pengurangan bentuk memungkinkan terbentuknya ruang-ruang dan bidang-bidang kosong di antara susunan ruang.

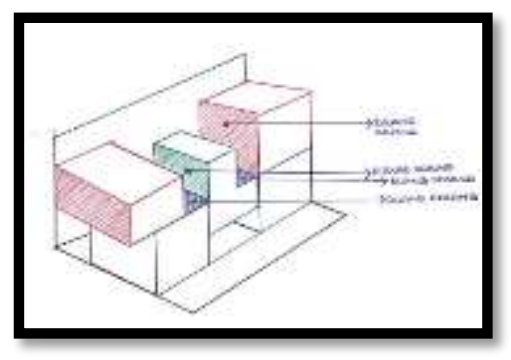

Gambar 7. Pengurangan Bentuk (Sumber: Analisis, 2017)

\section{Penataan Ruang Dalam Berdasarkan Jenis Kelamin}

Penataan ruang berdasarkan Jenis Kelamin didasarkan atas aturan-aturan dan normanorma agama dan budaya yang berlaku di 
Indonesia, yang sangat tegas menuntut adanya pemisahan ruang terutama untuk ruang tidur. Telah dijelaskan sebelumnya bahwa pemisahan ruang berdasarkan jenis kelamin merupakan hal yang mutlak harus dilakukan, sedangkan pemisahan berdasarkan usia masih memungkinkan dilakukan jika penghuni rumah sudah memiliki kemampuan secara ekonomi.

Pemisahan ruang tidur berdasarkan jenis kelamin dilakukan dengan mengelompokkan anak-anak perempuan di dalam satu ruang tidur dan anak-anak laki-laki di ruang tidur lainnya. Penataan furnitur di ruang tidur dapat menggunakan tempat tidur susun dengan maksimal kapasitas 4 orang dalam satu ruang tidur. Dengan berpedoman pada ukuran tempat tidur individual ( 1 orang) dalah $0,9 \mathrm{~m} \times$ $2 \mathrm{~m}$ maka minimal ukuran ruang adalah $6 \mathrm{~m}^{2}(2$ $\mathrm{m} \times 3 \mathrm{~m}$ ) untuk maksimum kapasitas 4 orang. Dari perhitungan tersebut terlihat bahwa ambang batas minimal rumah sederhana sehat sebesar $7,2 \mathrm{~m}^{2} /$ orang sangat sulit untuk dicapai, namun setidaknya pengupayaan kelayakan huni sebuah ruang tidur telah diupayakan melalui pemisahan jenis kelamin dan masuknya pencahayaan dan penghawaan ke dalam ruang.

\section{KESIMPULAN}

Keberadaan permukiman padat penduduk di kota-kota besar tidak dapat dihindari, selalu bertumbuh dari waktu ke waktu, yang tidak dapat diprediksi kapan akan terhenti. Penghuni rumah-rumah sangat sederhana di permukiman padat penduduk tersebut tidak menghuninya dalam waktu yang singkat, mereka dapat menempatinya bahkan sejak lahir hingga memiliki anak dan cucu. Dengan kurun waktu yang sedemikian lamanya menghuni rumah maka perlu dipikirkan dan diupayakan bagaimana rumah-rumah sangat sederhana ini didisain dengan mengedepankan faktor kenyamanan tinggal di dalamnya.

Kebutuhan standar manusia untuk dapat berkegiatan di dalam sebuah bangunan pada dasarnya memiliki kesamaan, terutama dari segi pemanfaatan ruang yang sesuai dengan fungsinya. Demikian juga halnya dengan rumah sangat sederhana di manapun dan bagi siapapun, harus dapat memenuhi kebutuhan standar penghuninya.

Dengan menggunakan modul besaran ruang pada bangunan rumah sangat sederhana yang memiliki luas lahan yang sangat kecil maka penataan ruang dapat diupayakan agar dapat memenuhi syarat penghunian sebuah ruang. Upaya tersebut meliputi pemenuhan kebutuhan ruang dari segi fungsi dan kenyamanan ruang.

Dari segi fungsi, tataan ruang harus dapat digunakan sesuai zoning ruang sehingga tidak terjadi tumpang tindih penggunaan yang menyebabkan terjadinya percampuran zoning terutama untuk zoning privat.

Dengan tercapainya kenyamanan ruang baik dari segi fungsi maupun dari segi pencahayaan dan penghawaan alami maka diharapkan aktivitas yang dapat dilakukan di dalam rumah akan lebih optimal.

\section{DAFTAR PUSTAKA}

[1] Depkimpraswil RI. (2002). Kepmenkimpraswil Nomor: 403/KPTS/M/2002 Tentang Pedoman Teknis Pembangunan Rumah Sederhana Sehat (Rs Sehat)

[2] Djumiko. 2012. Kajian Luas Rumah Sederhana Sehat Bagi Masyarakat Berpenghasilan Rendah. Harian Kompas

[3] Ashadi, Anisa, Ratna Dewi Nur'aini. (2017). Konsep Disain Rumah Sederhana Tipe Kecil Dengan Mempertimbangkan Kenyamanan Ruang. Jurnal Arsitektur NALARs Volume 16 No 1 Januari 2017. https://doi.org/10.24853/nalars.16.1.1-14 https://jurnal.umj.ac.id/index.php/nalars/arti cle/view/1016/926

[4] Ching, Francis DK. (2008). Arsitektur, Bentuk Ruang dan Tataan. Penerbit Erlangga.

[5] White, Edward T. Diterjemahkan oleh Ir. Sri Rahayu, dkk. (1986). Tata Atur Pengantar Merancang Arsitektur. Penerbit ITB Bandung, 
